\title{
Cell autonomous expression of inflammatory genes in biologically aged fibroblasts associated with elevated NF-kappaB activity Andres Kriete ${ }^{* 1,2}$, Kelli L Mayo ${ }^{1,2}$, Nirupama Yalamanchili ${ }^{1}$, William Beggs ${ }^{2}$, Patrick Bender ${ }^{2}$, Csaba Kari ${ }^{3}$ and Ulrich Rodeck ${ }^{3}$
}

Address: ${ }^{1}$ School of Biomedical Engineering, Science and Health Systems, Drexel University, Bossone Research Center, 3141 Chestnut Street, Philadelphia, PA 19104, USA, ${ }^{2}$ Coriell Institute for Medical Research, 403 Haddon Avenue, Camden, NJ 08103, USA and ${ }^{3}$ Dept. of Dermatology and Cutaneous Biology, Thomas Jefferson University, 233 South 10th Street, Suite 326 BLSB, Philadelphia, PA 19107, USA

Email: Andres Kriete* - ak3652@drexel.edu; Kelli L Mayo - mayokl@umdnj.edu; Nirupama Yalamanchili - ny29@drexel.edu; William Beggs - wgeggs@coriell.org; Patrick Bender - pbender@coriell.org; Csaba Kari - urodeck@mail.jci.tju.edu;

Ulrich Rodeck - ulrich.rodeck@mail.jci.tju.edu

* Corresponding author

Published: 16 July 2008

Immunity \& Ageing 2008, 5:5 doi:10.1186/1742-4933-5-5
Received: 18 March 2008

Accepted: 16 July 2008

This article is available from: http://www.immunityageing.com/content/5///5

(C) 2008 Kriete et al; licensee BioMed Central Ltd.

This is an Open Access article distributed under the terms of the Creative Commons Attribution License (http://creativecommons.org/licenses/by/2.0), which permits unrestricted use, distribution, and reproduction in any medium, provided the original work is properly cited.

\begin{abstract}
Background: Chronic inflammation is a well-known corollary of the aging process and is believed to significantly contribute to morbidity and mortality of many age-associated chronic diseases. However, the mechanisms that cause age-associated inflammatory changes are not well understood. Particularly, the contribution of cell stress responses to age-associated inflammation in 'non-inflammatory' cells remains poorly defined. The present cross-sectional study focused on differences in molecular signatures indicative of inflammatory states associated with biological aging of human fibroblasts from donors aged 22 to 92 years.
\end{abstract}

Results: Gene expression profiling revealed elevated steady-state transcript levels consistent with a chronic inflammatory state in fibroblast cell-strains obtained from older donors. We also observed enhanced NF- $\kappa B$ DNA binding activity in a subset of strains, and the NF- $\kappa B$ profile correlated with mRNA expression levels characteristic of inflammatory processes, which include transcripts coding for cytokines, chemokines, components of the complement cascade and MHC molecules. This intrinsic low-grade inflammatory state, as it relates to aging, occurs in cultured cells irrespective of the presence of other cell types or the in vivo context.

Conclusion: Our results are consistent with the view that constitutive activation of inflammatory pathways is a phenomenon prevalent in aged fibroblasts. It is possibly part of a cellular survival process in response to compromised mitochondrial function. Importantly, the inflammatory gene expression signature described here is cell autonomous, i.e. occurs in the absence of prototypical immune or pro-inflammatory cells, growth factors, or other inflammatory mediators.

\section{Background}

Chronic inflammation associated with the aging process has been implicated in a host of degenerative disease states including osteoarthritis, atherosclerosis, type- 2 dia- betes and even cancer [1-3]. Age-associated chronic inflammatory states are distinct from inflammation triggered by infection. It is presently unclear to what extent chronic inflammatory states in older individuals represent 
autoimmune processes caused by deregulation of the immune system $[4,5]$. Alternatively, these states may arise as a consequence of an increased cell stress response in old cells triggered by molecular damage incurred over a lifetime. In support of cell autonomous causes for age-associated inflammation, expression of inflammatory markers, such as cytokines, has been observed in cells subjected to replicative senescence in vitro caused by serial passaging [6-9]. However, molecular events observed during replicative senescence in vitro do not necessarily mirror events that occur in human aging, which is of a dramatically different time frame. This consideration motivated the present investigation of age-associated changes in proliferating fibroblasts derived from donors at different biological ages. Only few reports using fibroblasts aged in vivo have been published and these reports largely focused on age-associated changes in cell cycle progression of dividing cells $[10,11]$.

In contrast, in the present study we focused on 'inflammatory signatures', i.e. changes in gene expression patterns previously implicated in inflammatory states. Furthermore, we considered that determination of cell states associated with the aging process should be performed in quiescence rather than exponentially growing fibroblast cultures. This was based on the consideration that, under physiological conditions in tissues in vivo, the majority of fibroblasts neither proliferate nor have achieved replicative senescence akin to that of cultured fibroblasts. Therefore, we investigated differences in gene expression profiles of primary human fibroblasts derived from donors at different biological ages and rendered quiescent by growth factor starvation [12]. We report that expression of mRNA transcripts encoding proteins with roles in inflammation is elevated in fibroblasts derived from older individuals. This gene expression signature is associated with increased DNA binding of transcription factor nuclear factor kappa B (NF-אB) in a subset of aged cells and plays a role in mediating inflammatory responses.

\section{Methods \\ Cell Lines and Culture Procedures}

Human fibroblast cultures, established from skin samples derived from young and old donors, were obtained from the NIA Aging Cell Repository (Coriell Institute for Medical Research, Camden, NJ). All cell lines originated from 2 $\mathrm{mm}$ punch biopsies taken from the medial aspect of the upper arm. The donors were members of the Baltimore Longitudinal Study of Aging (BLSA) where they were characterized as "healthy" indviduals. The cell lines investigated had normal karyotypes. Coriell catalog numbers of these cell lines for the group of young donors were AG10803 (22 yrs), AG0454B (29 yrs), AG04441 (29-II yrs), AG13153 (30 yrs) and AG04438 (33 yrs), for the group of middle-age donors AG04456 (49 yrs), AG04659
(65 yrs), AG13369 (68-I yrs) and AG14251 (68-II yrs), and for the group of old donors AG11243 (74 yrs), AG09156 (81 yrs), AG13349 (86 yrs), AG13129 (89 yrs) and AG04064 (92 yrs). AG04456 (49 yrs) and AG14251 (68 yrs) were isogenic. Cells were grown in medium consisting of EMEM (Mediatech, Herndon, VA) supplemented with $2 \mathrm{mM}$ L-glutamine and 15\% FBS without antibiotics at $37^{\circ} \mathrm{C}$ and $5 \% \mathrm{CO}_{2}$ according to Coriell's standard procedures. To avoid the influence of replicative senescence, cell lines selected for our cultures had undergone no more than half of the maximum population doublings at which previously determined senescence would occur. Twenty four hours prior to RNA collection, cells were placed in growth factor-free medium (MEM supplemented with $0.2 \%$ Bovine Serum Albumin/BSA). The protocol to prepare cells for microarray gene expression analysis was as follows: (Day 1) Cells were plated at 9000-12000 cells per $\mathrm{cm}^{2}$ in regular growth medium; (Day 2) Cell culture medium was changed to growth-factor-free medium (EMEM with $0.2 \%$ BSA and $1 \% \mathrm{~L}$ glutamine); (Day 3) Cells were washed with ice cold phosphate-buffered saline (PBS). Qiagen lysis buffer (RLT) was used to prepare cell lysates which were stored at $-80^{\circ} \mathrm{C}$. Cell cycle distribution was determined by PI staining followed by FACS analysis. Percentage of cells in S-phase before starvation was generally $>10 \%$ and after mitogen starvation $<1 \%$.

\section{Microarray Analysis}

RNA was isolated from the cell lysate using Qiagen RNeasy mini kit according to the manufacturer's instructions. Gene expression analysis was performed using the Codelink human bioarray containing single-stranded 30-mer oligonucleotide probes (Applied Microarrays, Tempe, AZ) and chips were run in duplicate. Details of this platform are available on the vendor's homepage website. Characteristics of the Codelink platform have been evaluated by us [13] and as part of the microarray quality control (MAQC) assessment [14]. Sample preparation and hybridization followed procedures described by Young $e t$ al [13]. Slides were scanned at $5 \mu \mathrm{m}$ resolution with a ScanArray $4000 \times 1$ (Perkin Elmer, Waltham, Ma) and analyzed with the CodeLink Analysis Software, providing an integrated optical density (IOD) value for each hybridization spot, which is a measurement of an integrated background intensity value subtracted from the total pixel intensities within the area of the spot. Replicate readouts were averaged and normalized for differences between chips and outliers were detected. Expressions of characterized genes related to immunity and inflammation were identified and differential expressions determined. A variance filter trimmed the resulting list $(\mathrm{p}<0.15)$. We used a correlative approach to search for similarities between the $\mathrm{NF}-\kappa \mathrm{B}$ profile and expression of genes related to inflammation. In modification of previously used rank correla- 
tion for template matching of phenotypical markers $[15,16]$, we used Pearson correlation as a measure of similarity because the NF- $\mathrm{KB}$ values of the samples from young donors were close and within error margins, which can lead to low correlation values if ranked wrongly. Finally, the data was clustered by a dendrogram, using complete linkage analysis and a Canberra distance metric (J-Express, Molmine AS, Norway).

\section{NF- $\kappa$ B DNA Binding Activity Assay}

We analyzed the DNA binding activity of NF- $\mathrm{KB}$ p65/ RelA, a major component of the heterodimeric p50/RelA complex, with a chemiluminescent DNA binding assay in nuclear fractions. Cells were plated at subconfluency in regular growth medium. Twenty-four hours later, normal growth medium was replaced with a growth factor-free base medium for another 24 hours. On the day of sample collection, the cells ( 1.5 to $2 \times 10^{6} /$ sample) were washed once with PBS and trypsinized. They were centrifuged at $200-300 \times \mathrm{g}$ for 10 minutes and cell pellets were collected. The nuclear cell fractions were prepared using NEPER $^{\circledast}$ Nuclear and Cytoplasmic Extraction Reagents (Pierce Biotechnology, Product No. 78833, Rockford, IL) according to the manufacturer's instructions. $10 \mu \mathrm{g}$ of the nuclear cell fractions were used from each cell-line and their NF- $\mathrm{KB}$ p65 DNA binding activity was determined using the EZ-Detect NF- $\mathrm{BB}$ p65 Transcription Factor Kit (Pierce Biotechnology, Product No. 89859, Rockford, IL) according to the manufacturer's protocol. Two biological replicates of each sample were prepared and the signal of four readouts with a Veritas Microplate Luminometer was averaged.

\section{Results}

Previous efforts to identify age-associated changes in cellular homeostasis have largely relied on cells senesced in vitro or on the investigation of fast proliferating cells. In the present investigation, we focus on differences in quiescent fibroblasts derived from donors of different biological ages. Steady-state mRNA expression levels were determined by microarray analysis, as well as the NF- $\mathrm{KB}$ p65/RelA DNA binding assay in nuclear fractions. The NF$\mathrm{\kappa B}$ assay (Figure 1 ) revealed significantly higher binding activity in the middle-age (49-68 yrs) donors compared to the young (22-33 yrs) donors ( $\mathrm{p}=0.012$, independent one-tailed test) as well as higher binding activity in the old age (72-92 yrs) donors compared to the young ( $\mathrm{p}=$ $0.0039)$. However, the difference between the middle-age and old group was not significant ( $\mathrm{p}=0.34)$ and the combination of middle-age and old groups combined if compared to the young group gave a significant result $(\mathrm{p}=$ 0.004). The activity of the samples from the 68 and 86 year old donors were comparably low, and both of their gene expression profiles were different from those of the other older donors (Figure 2). The binding activity of NF- $\kappa \mathrm{B}$ in middle-age and old donors was significantly higher than young donors and was considered to be moderate in comparison to the positive control (TNF $\alpha$ treated HeLa cells) (Figure 1).

In the microarray analysis, thirty-four genes, listed in table 1 and sorted by their similarity to the NF- $\kappa B$ activity, constituted an inflammatory signature in middle-age and older cells. Of these genes, 17 have a correlation factor $\mathrm{R}$ $>0.3$ with the NF- $\kappa B$ profile. Genes representing a strong correlation with NF-kB included inflammatory genes such as FOS-like antigen 1 (FOSL1), antimicrobial peptide defensin beta one (DEFB1), T and B lymphocyte growth factor interleukin 2 (IL2), leukocyte modulator chemokine ligand 20 (CCL20) and cell adhesion molecule sialyltransferase 8A (SIAT8A). Elevated expression levels in cells from older individuals were observed for inflammatory cytokines including interleukin 1 receptor antagonist $(I L 1 R N)$, interferon, omega 1 (IFNW1), interleukin 2 (IL2), interleukin 1 alpha (IL1A), interferon induced transmembrane protein 1 (9-27) (IFITM1), interferon regulatory factor 7 (IRF7), and interferon induced transmembrane protein 1 (IFITM1) (9-27). Expression of mRNA encoding proteins involved in the immune responses in vivo was elevated including leukocyte receptor cluster (LRC) member 4 (LENG4), D component of complement, adipsin (DF), tumor necrosis factor superfamily, member 13b (TNFSF13B), and Fc fragment of IgG, low affinity IIIb, receptor for CD16 (FCGR3B). A subset of cell strains contained higher message levels of inflammatory related genes such as matrix metalloproteinase-13 (MMP-13), integrin beta 6 gene (ITGB6), a cell surface receptor mediating cell-adhesion, a sialidase enzyme (NEU-4) and a MHC class I related gene (HLA-G) with roles in antigen presentation, and, potentially, autoimmunity [17-20]. A remarkable group of genes with roles in the inflammatory response were elements of both the classical and alternative complement cascades, including complement component 4 binding protein, beta $(C 4 B P B)$, complement component $1, \mathrm{r}$ subcomponent $(C 1 R)$, and D component of complement, adipsin $(D F)$, which recognize, initiate, and execute the destruction of antigenic molecules. Furthermore, elevated transcripts of several chemokine ligands were found (CXCL2, CXCL9, CXCL14, CXCL20) and chemokine ligand 6/granulocyte chemotactic protein 2 (CXCLG), consistent with the potential of aged fibroblasts to chemoattract leukocytes as well as other inflammatory-related molecules modulating the immune response.

\section{Discussion}

Activation of the latent transcription factor NF- $\kappa \mathrm{B}$ plays a key role in mediating inflammatory responses and gene expression patterns [21]. It has also been demonstrated that genetically blocking NF- $\mathrm{B}$ in the skin of aged mice 


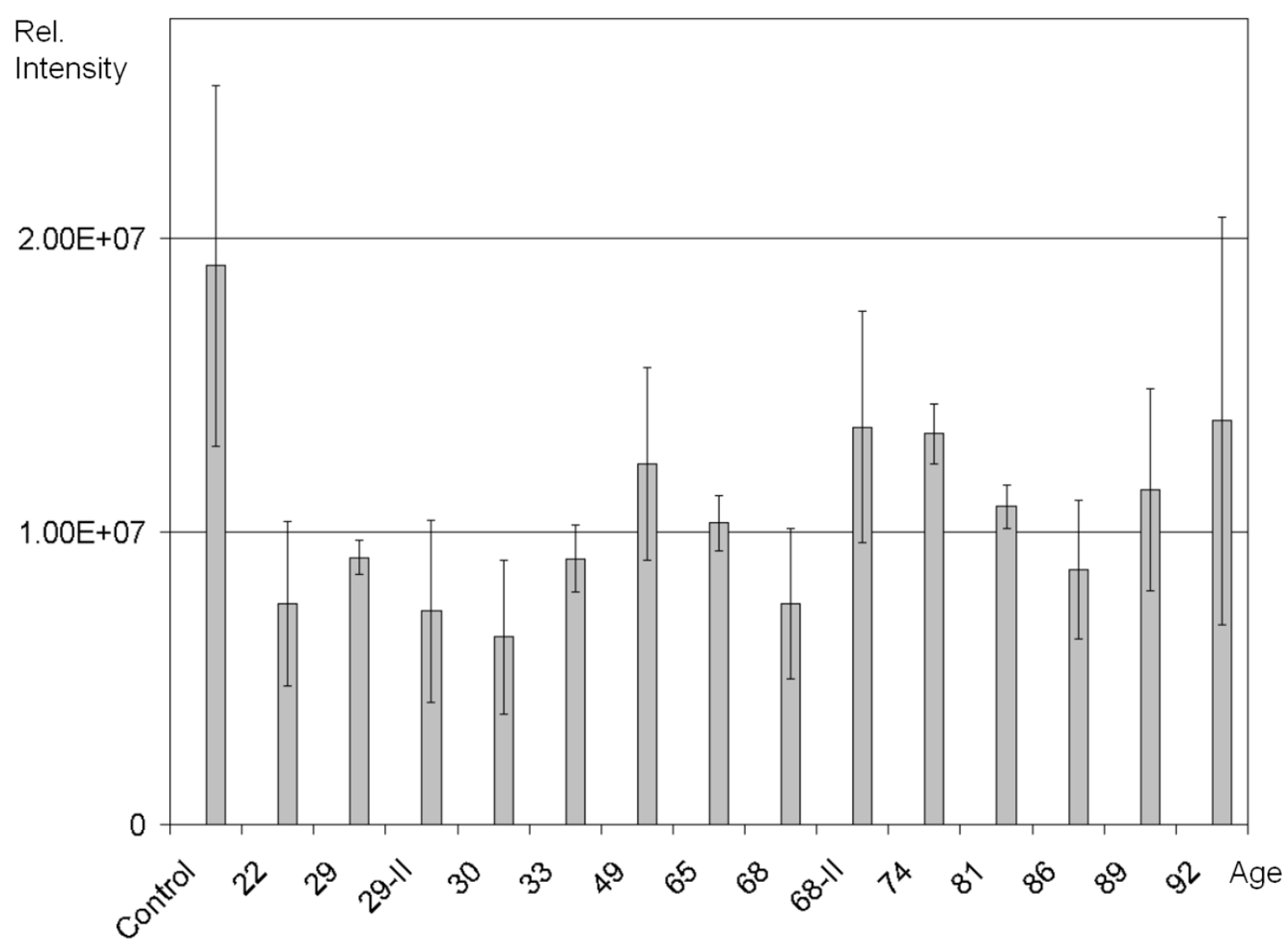

\section{Figure I}

NF- $\kappa$ B activity. Shown are the results of a DNA binding assay of the NF- $\kappa B$ p 65 transcription factor, using two biological replicates and four readouts for each sample. NF- $\kappa B$ activity, a key mediator of inflammation, is elevated in the nuclear fractions of fibroblasts from the group of older donors compared to young donors $(p<0.005)$. The DNA binding activity corresponds to a "low-grade" inflammatory state compared to the TNF $\alpha$ treated positive control.

reverses the gene expression pattern seen in aged cells as well as reverts the appearance of tissues to that of younger skin samples, illustrating the critical role of NF- $\mathrm{kB}$ in the aging phenotype $[22,23]$. Here we show that in human aging NF- $\mathrm{kB}$ becomes constitutively active, mediating enhanced transcription of inflammatory markers. Cytokines, chemokines, and components of the complement cascade dominated the upregulated genes. This is the first report to demonstrate that a low-grade inflammatory state, as it relates to aging, occurs in cell lines irrespective of the presence of other cell types or the in vivo context, which highlights that this inflammatory state is intrinsic and cell autonomous. While NF-kB appears to be an important regulator, the profile of inflammatory genes expressing at higher levels is still specific for each sample investigated and not all genes are regulated by NF- $\mathrm{KB}$, sug- gesting that additional factors may play a role mediating the profile.

It was reported that protein abundance of inflammatory markers parallels gene expression [24]; therefore it can be assumed that most inflammatory markers shown here would indeed contribute to the activation of the immune system, giving rise to a chronic inflammatory state in vivo. Specifically, fibroblasts acting as 'immune-competent' cells show higher levels of activity of molecules involved in antigen recognition, presentation and destruction such as FGR3B, DF and C1R. Essentially, aging cells send a destructive 'non-self message to the immune system, for which rheumatoid arthritis is a prime example. The production of cytokines may establish a positive feedback loop since these markers can also activate NF- $\mathrm{kB}$, and 


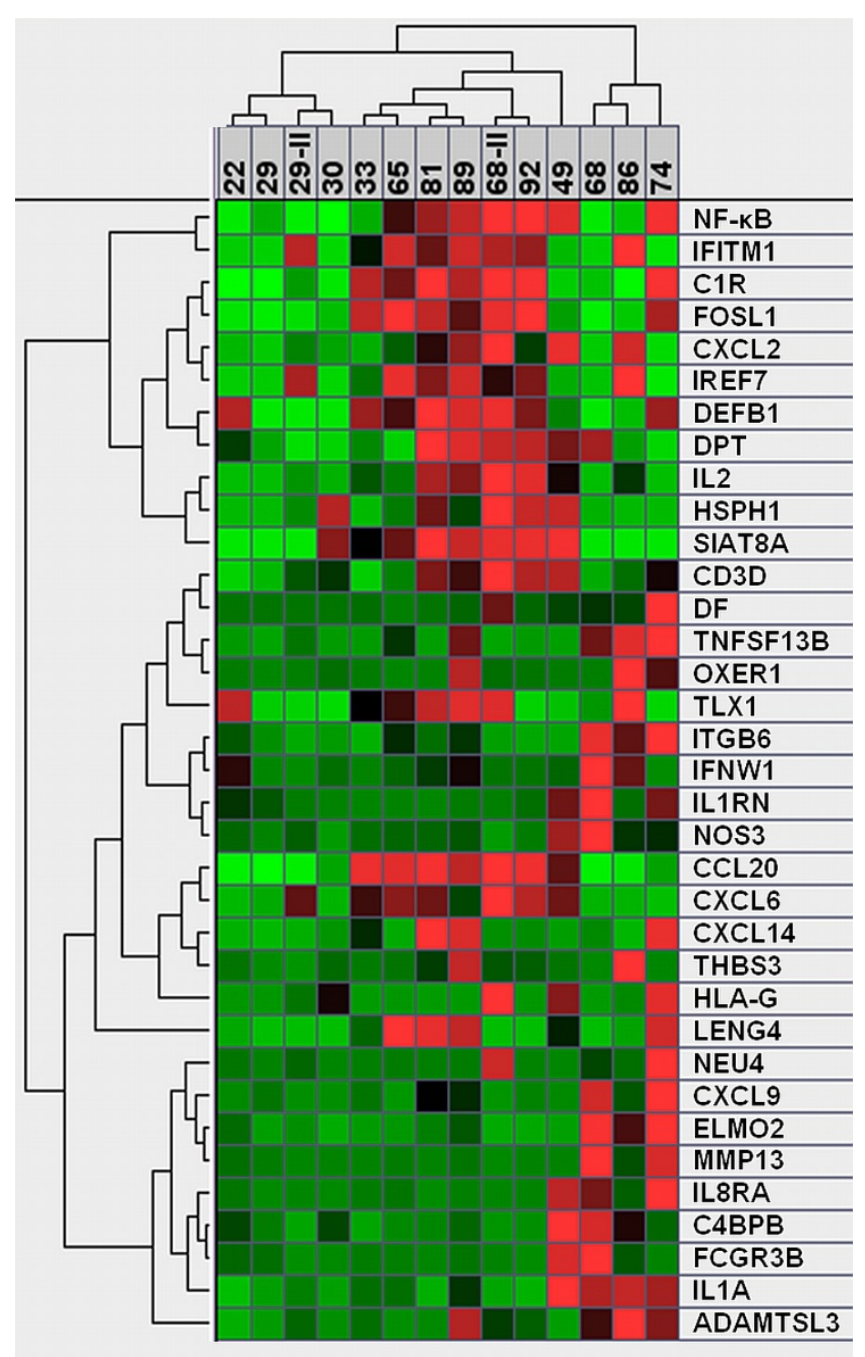

Figure 2

Heatmap of gene-expression of inflammatory markers. Green indicates repressed mRNA levels and red elevated levels. Intensities are normalized for each gene in each row. Samples and genes are grouped according to their similarity in profile, included is Nf- $\kappa \mathrm{B}$ activity in the first row. The dendrogram reveals distinct clusters preferentially grouping cytokines, chemokines and interferon related molecules, specifically expressed in each cell strain. Samples of young donors are distinct from the group of older donors, and the samples of the 68 and 86 old donors are distinct within the group of older donors.

herewith increase and prolong chronic inflammation [25]. Similarly, interferons, known to be produced by synovial fibroblasts, have been associated with prolonged $\mathrm{T}$ cell survival in rheumatic joints [26].

Multiple factors can contribute to the activation and posttranslational modification of NF- $\mathrm{B}[21,27]$, but as it relates to aging, cell-intrinsic factors can be traced back to mitochondrial dysfunction. It has been recognized that mitochondrial deficiency accompanies the aging process, albeit the exact mechanisms for mitochondrial dysfunction discussed, for example mtDNA mutations in vertebrates, remain controversial [28-31]. Since we did not find indications for increased levels of reactive oxygen species (ROS) and related expression of scavenger molecules (data not shown), we hypothesize that activating mechanisms of NF- $\mathrm{KB}$, as a consequence of mitochondrial dysfunction, may include other mechanisms such as accumulation of oxidized proteins and lipids in aged fibroblasts [32] or disturbances of intracellular calcium homeostasis [33,34]. Further, intracellular NADH abundance that has been related to defects in mitochondrial respiration is accompanied by inactivation of phosphatase and tensin homolg gene (PTEN). PTEN is a negative regulator of the Akt pathway [35,36], while Akt is known to converge with NF- $\mathrm{KB}$ signaling [35]. Insofar, NF- $\kappa B$ may participate in a retrograde response and crosstalk between dysfunctional mitochondria and nuclear genes as a cellular pro-survival mechanism. This would also explain why anti-inflammatory treatment regimes lead only to a temporary relief of symptoms, but would not correct for the primary cause of inflammation, which has its roots in cellular aging.

This study is a cross-sectional, rather a longitudinal study and the definition of age-groups follows the available samples in fulfillment of the stringent criteria set forth in the Method section. Variability as seen here is rooted in the process of biological aging, which is different from chronological age, and in cell selectivity during the initial establishment of cell cultures from biopsies. We also recognize that a study in vitro cannot capture the more complex interactions in vivo, involving other cellular participants and components of the immune system, which provoke, mediate, and amplify the primary cellular response. However, chronic inflammation has been implicated in many aging-associated conditions [1,37], and inflammatory markers described here have been reported in other age-related studies in which gene expression analysis was performed such as in brain [38], lung [39], liver [40], kidney [41] and coronary arteries [42]. Moreover, consensual findings show upregulation of NF$\kappa \mathrm{B}$ activity as a pivotal mediator of aging related inflammation in rodent and human tissues [22], including mouse brain, muscle [43-46] and human endothelial tissues [47], which suggests that similar processes as those observed here play a role in many other cell types and tissues.

\section{Conclusion}

Overall this study provides evidence for a cell-intrinsic activation of NF- $\mathrm{KB}$ and related upregulation of inflammatory markers. While inflammation is a protective host 
Table I: List of inflammatory genes. Given are accession numbers of genes, fold changes and p-values between the group of older and young donors, a Pearson correlation coefficient (R) expressing similarity to the NF- $\kappa$ B profile as seen in Figure I, and a description of genes.

\begin{tabular}{|c|c|c|c|c|}
\hline Accession ID & Fold & $\mathbf{p}$ & $\mathbf{R}$ & Description \\
\hline NM_00I733 & 2.3 & 0.023 & 0.74 & complement component I, $r$ subcomponent $(C I R)$ \\
\hline NM_005438 & 2.0 & 0.033 & 0.71 & FOS-like antigen I (FOSLI) \\
\hline NM_000732 & 2.0 & 0.012 & 0.69 & CD3D antigen, delta polypeptide (TiT3 complex) (CD3D) \\
\hline NM_000586 & 4.6 & 0.020 & 0.68 & interleukin 2 (IL2) \\
\hline NM_00459I & 2.0 & 0.068 & 0.65 & chemokine (C-C motif) ligand 20 (CCL20) \\
\hline NM_005218 & 2.1 & 0.066 & 0.61 & defensin, beta I (DEFBI) \\
\hline NM_002993 & 2.0 & 0.097 & 0.58 & chemokine (C-X-C motif) ligand 6 (granulocyte chemotactic protein 2) (CXCL6) \\
\hline NM_003034 & 2.8 & 0.040 & 0.58 & sialyltransferase 8A (GD3 synthase) (SIAT8A) \\
\hline NM_002I 27 & 3.5 & 0.104 & 0.56 & HLA-G histocompatibility antigen, class I, G (HLA-G) \\
\hline NM_006644 & 2.6 & 0.102 & 0.52 & heat shock 105 kDa/l 10 kDa protein I (HSPHI) \\
\hline NM_08074I & 6.1 & 0.093 & 0.49 & sialidase 4 (NEU4) \\
\hline NM_002089 & 2.4 & 0.020 & 0.46 & chemokine (C-X-C motif) ligand 2 (CXCL2) \\
\hline NM_001928 & 5.6 & 0.094 & 0.45 & D component of complement (adipsin) (DF) \\
\hline NM_00I937 & 2.2 & 0.017 & 0.41 & dermatopontin (DPT) \\
\hline NM_000634 & 4.3 & 0.068 & 0.39 & interleukin 8 receptor, alpha (IL8RA) \\
\hline NM_004887 & 3.5 & 0.047 & 0.38 & chemokine (C-X-C motif) ligand I4 (CXCLI4) \\
\hline NM_024298 & 6.8 & 0.023 & 0.30 & leukocyte receptor cluster (LRC) member 4 (LENG4) \\
\hline NM_002416 & 3.6 & 0.068 & 0.22 & chemokine (C-X-C motif) ligand 9 (CXCL9) \\
\hline NM_006573 & 3.3 & 0.040 & 0.17 & tumor necrosis factor (ligand) superfamily, member I3b (TNFSFI3B) \\
\hline NM_000575 & 2.7 & 0.033 & 0.17 & interleukin I, alpha (ILIA) \\
\hline NM_00364I & 2.0 & 0.088 & 0.13 & interferon induced transmembrane protein I (9-27) (IFITMI) \\
\hline NM_000888 & 3.2 & 0.042 & 0.09 & integrin, beta 6 (ITGB6) \\
\hline NM_00552I & 2.0 & 0.094 & 0.06 & T-cell leukemia, homeobox I (TLXI) \\
\hline NM_00403I & 2.0 & 0.064 & 0.05 & interferon regulatory factor 7 (IRF7), transcript variant $d$ \\
\hline NM_000716 & 2.2 & 0.085 & 0.05 & complement component 4 binding protein, beta (C4BPB) \\
\hline NM_007III2 & 4.7 & 0.073 & 0.04 & thrombospondin 3 (THBS3) \\
\hline NM_182764 & 3.4 & 0.061 & 0.04 & engulfment and cell motility 2 (ELMO2), transcript variant 3 \\
\hline NM_2075I7 & 2.7 & $0.04 I$ & 0.01 & ADAMTS-like 3 (ADAMTSL3) \\
\hline NM_I 148962 & 4.8 & 0.083 & -0.03 & oxoeicosanoid (OXE) receptor I (OXERI) \\
\hline NM_002427 & 5.1 & 0.093 & -0.11 & matrix metalloproteinase 13 (collagenase 3) (MMPI3) \\
\hline NM_000570 & 3.3 & 0.094 & -0.15 & Fc fragment of IgG, low affinity IIlb, receptor for (CDI6) (FCGR3B) \\
\hline NM_000577 & 2.7 & 0.116 & -0.19 & interleukin I receptor antagonist (ILIRN), transcript variant 3 \\
\hline NM_000603 & 2.4 & 0.088 & -0.21 & nitric oxide synthase 3 (endothelial cell) (NOS3) \\
\hline NM_002177 & 2.3 & 0.127 & -0.33 & interferon, omega I (IFNWI) \\
\hline
\end{tabular}

response against harmful external stimuli, in the context of biological aging this once beneficial response becomes constitutively active, potentially as a consequence of mitochondrial dysfunction. This may in turn mediate susceptibility to age-related diseases in tissues since aberrant expression of inflammatory markers plays a key role in pathogenesis and tumorgenesis. Our study may provide a preliminary diagnostic tool to profile aging at the cellular level.

\section{Abbreviations}

NADH: Nicotinamide adenosine dinucleotide hydrogen; PTEN: Phosphatase and tensin homolog gene; ROS: Reactive oxygen species; NF- $\kappa \mathrm{B}$ : Transcription factor nuclear factor kappa B; TNF: Tumor necrosis factor.

\section{Competing interests}

The authors declare that they have no competing interests.

\section{Authors' contributions}

AK, KLM and UR designed research, NY, WB and CK performed research, AK, KLM, WB and PB analyzed data, AK, KLM and UR wrote the paper.

\section{Acknowledgements}

We thank Christine Beiswanger for providing cell-lines from the Coriell Cell Repositories, Ruth Goldman for support in cell culturing, Donald Coppock for many elucidating discussions, Randell Lockner (Applied Microarrays, Tempe, AZ) for advice in microarray analysis, as well as Qing Ren for advice on the NF- $\mathrm{KB}$ assay and Marlene R.D. Quadros (Thomas Jefferson University) for overall support.

\section{References}

I. Sarkar D, Fisher PB: Molecular mechanisms of aging-associated inflammation. Cancer Lett 2006, 236(I): I3-23.

2. Licastro F, Candore G, Lio D, Porcellini E, Colonna-Romano G, Franceschi C, Caruso C: Innate immunity and inflammation in ageing: a key for understanding age-related diseases. Immun Ageing 2005, 2:8. 
3. Yung RL: Changes in immune function with age. Rheum Dis Clin North Am 2000, 26(3):455-473.

4. Salminen A, Huuskonen J, Ojala J, Kauppinen A, Kaarniranta K, Suuronen $T$ : Activation of innate immunity system during aging: NF-kB signaling is the molecular culprit of inflamm-aging. Ageing Res Rev 2007.

5. Franceschi C, Capri M, Monti D, Giunta S, Olivieri F, Sevini F, Panourgia MP, Invidia L, Celani L, Scurti M, Cevenini E, Castellani GC, Salvioli $\mathrm{S}$ : Inflammaging and anti-inflammaging: a systemic perspective on aging and longevity emerged from studies in humans. Mech Ageing Dev 2007, I 28(I):92-105.

6. Krtolica A, Campisi J: Cancer and aging: a model for the cancer promoting effects of the aging stroma. Int J Biochem Cell Biol 2002, 34(II): I $40|-| 4 \mid 4$.

7. Mariotti M, Castiglioni S, Bernardini D, Maier JA: Interleukin I alpha is a marker of endothelial cellular senescent. Immun Ageing 2006, 3:4.

8. Shelton DN, Chang E, Whittier PS, Choi D, Funk WD: Microarray analysis of replicative senescence. Curr Biol 1999, 9(17):939-945.

9. Zhang H, Pan KH, Cohen SN: Senescence-specific gene expression fingerprints reveal cell-type-dependent physical clustering of up-regulated chromosomal loci. Proc Natl Acad Sci U S A 2003, $100(6): 325 I-3256$.

10. Ly DH, Lockhart DJ, Lerner RA, Schultz PG: Mitotic misregulation and human aging. Science 2000, 287(5462):2486-2492.

II. Geigl JB, Langer S, Barwisch S, Pfleghaar K, Lederer G, Speicher MR: Analysis of gene expression patterns and chromosomal changes associated with aging. Cancer Res 2004, 64(23):8550-8557.

12. Coller HA, Sang L, Roberts JM: A new description of cellular quiescence. PLoS Biol 2006, 4(3):e83.

13. Young MB, DiSilvestro MR, Sendera TJ, Freund J, Kriete A, Magnuson $S R$ : Analysis of gene expression in carbon tetrachloridetreated rat livers using a novel bioarray technology. Pharmacogenomics J 2003, 3(I):41-52.

14. Canales RD, Luo Y, Willey IC, Austermiller B, Barbacioru CC, Boysen C, Hunkapiller K, Jensen RV, Knight CR, Lee KY, Ma Y, Maqsodi B, Papallo A, Peters EH, Poulter K, Ruppel PL, Samaha RR, Shi L, Yang W, Zhang L, Goodsaid FM: Evaluation of DNA microarray results with quantitative gene expression platforms. Nat Biotechnol 2006, 24(9): I II5- I I22.

15. Kriete A, Anderson MK, Love B, Freund J, Caffrey JJ, Young MB, Sendera TJ, Magnuson SR, Braughler JM: Combined histomorphometric and gene-expression profiling applied to toxicology. Genome Biol 2003, 4(5):R32.

16. Boyce K, Kriete A, Nagatomi S, Kelder B, Coschigano K, Kopchick J]: Phenotypical enrichment strategies for microarray data analysis applied in a type II diabetes study. Omics 2005, 9(3):25I-265.

17. Gaczynska M, Rock KL, Goldberg AL: Gamma-interferon and expression of MHC genes regulate peptide hydrolysis by proteasomes. Nature 1993, 365(6443):264-267.

18. Seyrantepe V, Landry K, Trudel S, Hassan JA, Morales CR, Pshezhetsky AV: Neu4, a novel human lysosomal lumen sialidase, confers normal phenotype to sialidosis and galactosialidosis cells. J Biol Chem 2004, 279(35):3702I-37029.

19. Herouy Y, Mellios P, Bandemir E, Dichmann S, Nockowski P, Schopf $E$, Norgauer J: Inflammation in stasis dermatitis upregulates MMP-I, MMP-2 and MMP-I3 expression. J Dermatol Sci 200I, 25(3): 198-205.

20. Puthawala K, Hadjiangelis N, Jacoby SC, Bayongan E, Zhao Z, Yang Z Devitt ML, Horan GS, Weinreb PH, Lukashev ME, Violette SM, Grant KS, Colarossi C, Formenti SC, Munger JS: Inhibition of integrin alpha(v)beta6, an activator of latent transforming growth factor-beta, prevents radiation-induced lung fibrosis. $\mathrm{Am} J$ Respir Crit Care Med 2008, I77(I):82-90.

21. Perkins ND: Integrating cell-signalling pathways with NF-kappaB and IKK function. Nat Rev Mol Cell Biol 2007, 8(I):49-62.

22. Adler AS, Sinha S, Kawahara TL, Zhang JY, Segal E, Chang HY: Motif module map reveals enforcement of aging by continual NF\{kappa\}B activity. Genes Dev 2007, 2 I(24):3244-3257.

23. Adler AS, Kawahara TL, Segal E, Chang HY: Reversal of aging by NFkappaB blockade. Cell Cycle 2008, 7(5):556-559.

24. Prabhakar U, Conway TM, Murdock P, Mooney JL, Clark S, Hedge P, Bond BC, Jazwinska EC, Barnes MR, Tobin F, Damian-lordachi V,
Greller L, Hurle M, Stubbs AP, Li Z, Valoret El, Erickson-Miller C, Cass L, Levitt B, Davis HM, Jorkasky DK, Williams WV: Correlation of protein and gene expression profiles of inflammatory proteins after endotoxin challenge in human subjects. DNA Cell Biol 2005, 24(7):4|0-43|

25. Pahl HL: Activators and target genes of Rel/NF-kappaB transcription factors. Oncogene 1999, 18(49):6853-6866.

26. Pilling D, Akbar AN, Girdlestone J, Orteu CH, Borthwick NJ, Amft N, Scheel-Toellner D, Buckley CD, Salmon M: Interferon-beta mediates stromal cell rescue of $\mathbf{T}$ cells from apoptosis. Eur J Immunol 1999, 29(3): I04I-1050.

27. Janssens S, Tschopp J: Signals from within: the DNA-damageinduced NF-kappaB response. Cell Death Differ 2006, 13(5):773-784.

28. Trifunovic A, Wredenberg A, Falkenberg M, Spelbrink JN, Rovio AT, Bruder CE, Bohlooly YM, Gidlof S, Oldfors A, Wibom R, Tornell J, Jacobs HT, Larsson NG: Premature ageing in mice expressing defective mitochondrial DNA polymerase. Nature 2004, 429(6990):417-423.

29. Lim KS, Jeyaseelan K, Whiteman M, Jenner A, Halliwell B: Oxidative damage in mitochondrial DNA is not extensive. Ann $N$ Y Acad Sci 2005, 1042:210-220.

30. Khrapko K, Kraytsberg Y, de Grey AD, Vijg J, Schon EA: Does premature aging of the mtDNA mutator mouse prove that mtDNA mutations are involved in natural aging? Aging Cell 2006, 5(3):279-282.

31. Kujoth GC, Bradshaw PC, Haroon S, Prolla TA: The role of mitochondrial DNA mutations in mammalian aging. PLoS Genet 2007, 3(2):e24.

32. Maziere C, Auclair M, Djavaheri-Mergny M, Packer L, Maziere JC: Oxidized low density lipoprotein induces activation of the transcription factor NF kappa B in fibroblasts, endothelial and smooth muscle cells. Biochem Mol Biol Int 1996, 39(6): $1201-1207$

33. Biswas G, Adebanjo OA, Freedman BD, Anandatheerthavarada HK, Vijayasarathy C, Zaidi M, Kotlikoff M, Avadhani NG: Retrograde $\mathrm{Ca2}+$ signaling in $\mathrm{C} 2 \mathrm{Cl} 2$ skeletal myocytes in response to mitochondrial genetic and metabolic stress: a novel mode of inter-organelle crosstalk. Embo J 1999, 18(3):522-533.

34. Biswas G, Anandatheerthavarada HK, Zaidi M, Avadhani NG: Mitochondria to nucleus stress signaling: a distinctive mechanism of NFkappaB/Rel activation through calcineurin-mediated inactivation of IkappaBbeta. J Cell Biol 2003, I6 I(3):507-5 I9.

35. Meng F, Liu L, Chin PC, D'Mello SR: Akt is a downstream target of NF-kappa B. J Biol Chem 2002, 277(33):29674-29680.

36. Pelicano H, Xu RH, Du M, Feng L, Sasaki R, Carew JS, Hu Y, Ramdas L, Hu L, Keating MJ, Zhang W, Plunkett W, Huang P: Mitochondrial respiration defects in cancer cells cause activation of Akt survival pathway through a redox-mediated mechanism. J Cell Biol 2006, I75(6):913-923.

37. Chung HY, Kim HJ, Kim JW, Yu BP: The inflammation hypothesis of aging: molecular modulation by calorie restriction. Ann $N$ Y Acad Sci 200I, 928:327-335.

38. Lu T, Pan Y, Kao SY, Li C, Kohane I, Chan J, Yankner BA: Gene regulation and DNA damage in the ageing human brain. Nature 2004, 429(6994):883-891.

39. Aoshiba $K$, Nagai $A$ : Chronic lung inflammation in aging mice. FEBS Lett 2007, 58 I ( 18):35 I2-35 I6.

40. Kelder B, Boyce K, Kriete A, Clark R, Berryman DE, Nagatomi S, List $E O$, Braughler M, Kopchick JJ: CIDE-A is expressed in liver of old mice and in type 2 diabetic mouse liver exhibiting steatosis. Comp Hepatol 2007, 6:4.

41. Rodwell GE, Sonu R, Zahn JM, Lund J, Wilhelmy J, Wang L, Xiao W, Mindrinos M, Crane E, Segal E, Myers BD, Brooks JD, Davis RW, Higgins J, Owen $A B, K i m$ SK: A transcriptional profile of aging in the human kidney. PLoS Biol 2004, 2(I 2):e427.

42. Csiszar A, Ungvari Z, Koller A, Edwards JG, Kaley G: Aging-induced proinflammatory shift in cytokine expression profile in coronary arteries. Faseb J 2003, 17(9): I | 83-I I 85.

43. Helenius M, Hanninen M, Lehtinen SK, Salminen A: Aging-induced up-regulation of nuclear binding activities of oxidative stress responsive NF-kB transcription factor in mouse cardiac muscle. J Mol Cell Cardiol I996, 28(3):487-498.

44. Korhonen P, Helenius M, Salminen A: Age-related changes in the regulation of transcription factor NF-kappa B in rat brain. Neurosci Lett 1997, 225(I):6I-64. 
45. Kim HJ, Kim KW, Yu BP, Chung HY: The effect of age on cyclooxygenase-2 gene expression: NF-kappaB activation and lkappaBalpha degradation. Free Radic Biol Med 2000, 28(5):683-692.

46. Bar-Shai M, Carmeli E, Reznick AZ: The role of NF-kappaB in protein breakdown in immobilization, aging, and exercise: from basic processes to promotion of health. Ann N Y Acad Sci 2005, 1057:43I-447.

47. Donato AJ, Eskurza I, Silver AE, Levy AS, Pierce GL, Gates PE, Seals DR: Direct evidence of endothelial oxidative stress with aging in humans: relation to impaired endothelium-dependent dilation and upregulation of nuclear factor-kappaB. Circ Res 2007, 100(II):1659-1666.

Publish with Bio Med Central and every scientist can read your work free of charge

"BioMed Central will be the most significant development for disseminating the results of biomedical research in our lifetime. "

Sir Paul Nurse, Cancer Research UK

Your research papers will be:

- available free of charge to the entire biomedical community

- peer reviewed and published immediately upon acceptance

- cited in PubMed and archived on PubMed Central

- yours - you keep the copyright

Submit your manuscript here:

http://www.biomedcentral.com/info/publishing_adv.asp 